\title{
ECOLOGY OF SOME TERRESTRIAL MOLLUSCS IN SHARKIA AND ISMAILIA GOVERNORATE
}

\author{
RADY,G.H. ${ }^{1}$, A.A. ABDELGAWAD ${ }^{1}$, SH.A. ISMAIL ${ }^{2}$, M.H.LOKMA ${ }^{2}$ \\ 1. Plant Protection Department, Fac. of Agric., Benha Univ. \\ 2. Plant Protection Research Institute, ARC,Doki,Giza, Egypt.
}

(Manuscript received 23 March 2014)

\begin{abstract}
Field studies were carried out to survey, population density and importance value of terrestrial molluscs infesting some vegetable and field crops. Survey studies revealed that five species were found infesting different crops in Ismailia and Sharkia governorate. These species were Monacha cartusiana, Cochlicella acuta, Succinea putris, Deroceras leave and Deroceras reticulatum,.The last species was recorded for the first time in Ismailia governorate. Population density were counted on host plants at three districts of Sharkia and Ismailia governorate during two successive growing seasons February to May 2008 and 2009 respectively. Generally, It is clear that the glassy clover snail $M$. cartusiana was the predominant species on field and vegetable crops. On the other hand population density of land snails differed from host plant to another and also from locality to another. Finally, The land snail species can be arranged descedingly according to its importance values at Sharkia and Ismailia as follows: $M$. cartusiana $>S$. putris $>D$. reticulatum and $M$. cartusiana $>S$. putris $>D$. reticulatum $>D$. leave $>C$. acuta, respectively.
\end{abstract}

\section{INTRODUCTION}

Terrestrial molluscs has been become one of the most serious pests in different localities especially north and east delta region. In addition, some gastropods work as intermediate hosts for many parasitic worms infesting man and his domestic animals (Godan, 1983 In recent years, terrestrial snails have increased rapidly in all crops causing economic damage in the field crops, vegetables as well as horticultural crops. In some countries such as in Chile,1984, where find living snails Cernuella virgata in a shipment of barely from South Australia.this one rejection cost the Australian Barely Board 13 million A \$ In compensation payment (Baker,1989). In Egypt, land snails were detected in different governorate attacking many economic crops. For instances, $H$. vestalis, Theba pisana and $M$. cartusiana were most in jurions in northern Egypt (Kassab and Daoud, 1964), Monacha sp. and Oxychilus sp. were detected in El- Ismaeilia governorate ( El- Okda, 1984). On the other hand many authers surveyed land snails in Sharkia governorate (Ghamry et al.,1993, Ismail, 1997, Abdel Aal, 2001,Mahrous et al,2002, Arafa,2006 and Lokma, 2007). In Ismailia 
Governorate, (Shoeib Maha, 2008). Recorded that M. cartusiana, E. vermiculata, C. acuta, and $H$. vestalis, Theba pisana, $D$. leave and D. reticulatum were surveyed in certain localities attacking many crops at Ismailia Governorate. The present study was to throw light on identity, population density as well as importance value of terrestrial molluscs at Sharkia and Ismailia governorate.

\section{MATERIALS AND METHODS}

\section{Survey and population density of terrestrial gastropods in Sharkia and Ismailia governorate.}

Survey study of terrestrial snail and slug species attacking numerous host plants, were curried out in some localities at two governorate, Sharkia (AbouHammad, Fakous and Mashtool-El Souk) and Ismailia (Ismailia El Balad, El- Kassasin El-Gadida, and Fayed) during two successive growing seasons through the activity period from February to May 2008 and 2009.

Four localities (villages) were chosen as representatives of each district.These localities in districts of Sharkia governorate were El-Kheis, El-Abbasa, El-Gaavaria and El-Qurain (Abou-Hammad), Fakous El-Balad, El-Khattara, Abou-Shalaby and ELFadadna (Fakous), and Mashtoul El-Balad, El- Monaier, Kafr Ebrash and ElSahava(Mashtool -El-Souk). While localites in distracts of Ismailia governorate were (Om-Azam, Al-Dawawis, El-Koqh and El-Mahsama El-Kadima (El -Kassasin ElGadida), El-Firdan, El-Wasfia, Abou Atwa and Dabiaya (Ismailia EL-Balad), and (Fayed El-Balad, Kasfaryeet, Abou-Soltan and Sarabioum El-Mahata, (Fayed) .Numbers of snails were counted on certain field crops i.e broad bean Vicia faba, Egyptian clover, Trifollium alexandrinum, maize Zae mays, onion Allium cepa, wheat, Triticum aestivum and vegetable crops i.e. cabbage, Brassica oleraceae var. cabitata, cucumber Cucumis sativus, egg plant, Solanum melongena, pepper, Capsicum annum, squash Cucurbita pepo, strawberry, Fragaria ananassa, tomato Lycopersicon esculentum, watermelon, Citrullus vulgaris, kidney bean, Phaseolus vulgaris and taro, Arum colocasia.

Samples were taken in early morning by using the quadrated sample size $50 \times$ $50 \mathrm{~cm}$ (Staikou and Lazaridou-Dimitriadou 1990). Five randomly samples were taken from each crop in the surveyed localities. All snails and slugs found on plants or on soil surface in the qauadrate were counted. 


\section{Importance value of the identified gastropods in sharkia and Ismailia governorate.}

The total numbers of 360 samples were randomly collected from the examined crops mentioned before in three districts of Sharkia and Ismailia governorate. Samples were conducted in early morning during the activity period started from February to May in 2008 and 2009. Samples were taken in field and vegetable crops according to(Staikou and Lazaridou-Dimitriadou 1990). Ten adult snails collected from each of the surveyed districts were weighed and average biomass for each species was calculated. Absolute and relative frequency occurrence as well as population density were determined according to Norton (1978) as follows: Absolute frequency occurrence $=$

$$
\frac{\text { Numberof samples containing a species }}{\text { Numberof sample examined }} \times 100
$$

Relative frequency occurrence $=$

$$
\frac{\text { Absolute frequency occurrence of species }}{\text { Sum of frequency occurrence of all species }} \times 100
$$

Absolute density =

$$
\begin{aligned}
& \text { Total number of individusl of species } \\
& \text { Number of samples containing this species } \\
& \text { Relative density }= \\
& \frac{\text { Number of individual s of species }}{\text { Sum of individuals of all species }} \times 100 \\
& \text { Relative biomass }=\frac{\text { Absolute biomass of species }}{\text { Sum of biomass of all species }} \times 100
\end{aligned}
$$

\section{RESULTS AND DISCUSSION}

\section{Survey studies of land gastropods in certain districts in Sharkia and Ismailia governorate.}

The objective of the present study is to determine land gastropod species occurred in the infested localities of Sharkia and Ismailia governorate. Results revealed in that five species of terrestrial gastropods belonging to different families of order: Stylommatophora, were found in different localities of Sharkia and Ismailia governorate. These families were Hygromiidae, Helicidae, Succineidae and Limicidae. 
The family Hygromiidae was presented by the glassy clover snail, Monacha cartusiana (Muller), the family Helicidae, conical snail, Cochlicella acuta (Muller), the family: succineidae contained, Succinea putris, (Linnaeus) while the family: Limicidae included two slug species i.e., the field slug, Deroceras reticulatum (Muller) and the Smooth (marsh) slug, D. leave (Muller). The infested localities (villages) with land gastropods in 3 districts of Sharkia and Ismailia governorate are the infested Data in Table (1) showed that host plants infested with land moullsc species in tested localities at three districts of Sharkia and Ismailia governorate during two successive seasons 2008 and 2009. It is clear that the glassy clover snail,Monacha cartusiana infested most of the examined field and vegetables crops i.e. Egyptian clover, broad bean, wheat, onion, maize and cucumber, egg plant, squash, strawberry, tomato and kidney bean in Sharkia and Ismailia governorate. On the other hand, the amber snail Succinia putris was found on broad bean, Egyptian clover, wheat, and onion (field crops) and cabbage, strawberry and tomato (vegetable crops) at Sharkia governorate. Regarding at Ismailia Governorate, the amber snail was found on Egyptian clover and wheat (field crops) and vegetable crops i.e tomato and watermelon. The conical snail Cochlicella acuta was detected mainly on Egyptian clover and kidney bean (field crops) and on tomato and kidney bean (vegetable crops) in Kasfaryt, locality, Fayed district, Ismailia governorate.The other identified species were determined with limited occurrence in the inspected localities of Sharkia and Ismailia governorate. For instances, the field slug Deroceras reticulatum was detected on Egyptian clover and tomato in El-Sahava village, Mashtool- El-Souk district, Sharkia Governorate. Finally Deroceras leave was found on Egyptian clover in El-Mahsama El-Kadima locality,ElKasassin El-Gdida district and Sarabyoum El-Mahata, Fayed district, Ismailia governorate, while it was found on wheat at Sarabyoum El-Mahata, Fayed district, Ismailia governorate, while it was found on wheat at Om-Azzam,village, El-Ksassin ElGdida district, Ismailia governorate, and on tomato in Om -Azzam and watermelon in El-Mahsama El-Kadima and El- Kassasin El-Gdida districts, Ismailia governorate ,respectively. It is necessary to mention here that the field slug Deroceras reticulatum was recorded for the first time on strawberry and Egyptian clover in El-Mahsama ElKadima and El-Dabaya (El-Ksasin El-Gadida and Ismailia El-Balad districts), respectively at Ismailia governorate.

An extensive survey was carried out on terrestrial molluscs infesting different crops at 12 localities representing 3 districts belonging to Sharkia and Ismailia Governorate. 
Table 1. Terrestrial molluscus species infesting major crops in certain localities at three districts of Ismailia and Sharkhia governorate.

\begin{tabular}{|c|c|c|c|c|c|c|c|c|c|c|c|c|c|c|c|c|c|}
\hline \multirow[b]{2}{*}{ Governorate } & \multirow[b]{2}{*}{ Districts } & \multirow[b]{2}{*}{ Localities } & \multicolumn{5}{|c|}{ Field crops } & \multicolumn{10}{|c|}{ Vegetables crops } \\
\hline & & & 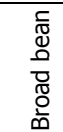 & 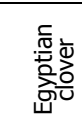 & $\frac{\stackrel{N}{N}}{\stackrel{N}{\tilde{N}}}$ & .․ㅡㅇ & 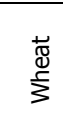 & 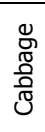 & 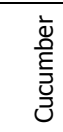 & 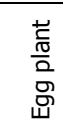 & $\begin{array}{l}\overline{\grave{0}} \\
\frac{0}{\overline{0}} \\
\overline{0}\end{array}$ & 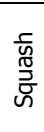 & 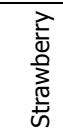 & 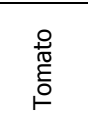 & 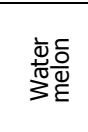 & 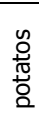 & 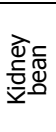 \\
\hline \multirow{10}{*}{ 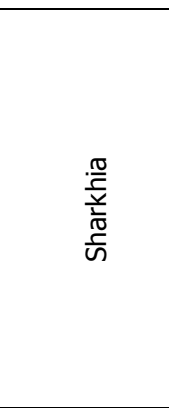 } & \multirow{3}{*}{ Abou-Hammad } & El-Khais & - & SM & - & - & - & - & - & - & - & - & - & - & - & - & - \\
\hline & & El-Gavaria & - & SM & - & - & $\mathrm{M}$ & - & - & M & - & - & - & $\mathrm{M}$ & - & - & - \\
\hline & & El-qurana & - & SM & - & - & $\mathrm{S}$ & - & - & - & - & - & - & - & - & - & - \\
\hline & \multirow[b]{3}{*}{ Fakous } & El-Khataraha & - & $\mathrm{M}$ & - & $\mathrm{M}$ & $\mathrm{M}$ & - & - & - & - & - & - & $M$ & - & - & $\mathrm{M}$ \\
\hline & & Abou-Shlaby & $M$ & $M$ & - & $M$ & $\mathrm{M}$ & - & - & $M$ & - & - & - & - & - & - & - \\
\hline & & Fakous El-balad & M & - & - & M & M & - & - & - & - & - & - & - & - & - & - \\
\hline & \multirow{4}{*}{ Mashtooul -El Souq } & Moniuer & - & MS & - & $\mathrm{M}$ & - & $\mathrm{S}$ & - & - & - & - & - & $\mathrm{S}$ & - & - & - \\
\hline & & Kafr-Ebrash & - & $M$ & - & - & - & - & - & - & - & - & - & - & - & - & - \\
\hline & & $\begin{array}{l}\text { Mashtooul El- } \\
\text { balad }\end{array}$ & - & M & - & M & M & - & - & - & - & - & - & - & - & - & - \\
\hline & & El-Sahava & - & $\mathrm{MSD}_{2}$ & - & $\mathrm{S}$ & SM & - & - & - & - & - & MS & $\mathrm{MSD}_{2}$ & - & M & M \\
\hline \multirow{10}{*}{ 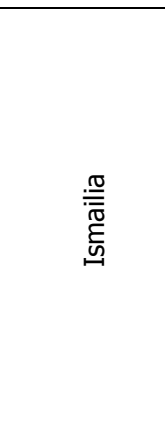 } & \multirow{4}{*}{ El-Ksasin -ElGdida } & Om-Azam & - & $\mathrm{M}$ & - & - & $D_{1} M$ & - & - & - & - & - & $D_{1} M$ & $M$ & - & - & - \\
\hline & & Al-Dawawis & - & MS & - & - & $\mathrm{S}$ & - & - & - & - & - & - & - & - & - & - \\
\hline & & El-Qoua & - & MS & - & - & MS & - & - & - & - & - & - & - & M & - & - \\
\hline & & $\begin{array}{l}\text { El-Mahsama El- } \\
\text { Kadima }\end{array}$ & - & $\mathrm{MSD}_{1}$ & - & - & M & - & - & - & - & - & $\mathrm{D}_{2} \mathrm{M}$ & MS & $\mathrm{MSD}_{1}$ & - & - \\
\hline & \multirow{2}{*}{ Ismailia } & El-Firdan & - & M & - & - & - & - & - & - & - & $M$ & $M$ & - & - & - & - \\
\hline & & El-Dabaya & - & $\mathrm{MD}_{2}$ & - & - & - & - & - & - & - & - & - & - & - & - & - \\
\hline & \multirow{4}{*}{ Fayed } & Kasfaryt & - & MSC & $M$ & - & $M$ & - & - & - & - & - & - & MC & - & - & MC \\
\hline & & Fayed EL-balad & - & MSC & - & - & MS & - & - & $M$ & - & - & - & MS & - & - & - \\
\hline & & Abou-Soltan & - & $M$ & - & $M$ & $\mathrm{M}$ & - & - & - & $\mathrm{M}$ & - & - & $M$ & - & - & - \\
\hline & & $\begin{array}{l}\text { Srabyoum El } \\
\text { mahata }\end{array}$ & - & $\mathrm{MSD}_{1}$ & - & - & M & - & - & - & - & - & M & $\mathrm{D}_{1} \mathrm{M}$ & - & - & $\mathrm{MD}_{1}$ \\
\hline
\end{tabular}

$\mathbf{M}=\mathbf{M}$. cartusiana

$\mathbf{S}=$ Succinea $\mathrm{sp}$

$\mathbf{C}=$ C. acuta

D1 = Deroceras leave

D2 = Deroceras reticulatum

- = No infestation 
Data presented in Table (2) revealed that the identified species mentioned previously varied in their incidence and level of infestation according to locality and host plant. It is obvious that $M$. artusiana has the upper one in snails incidence compared to other species, since it was recorded in all surveyed localities.

Moreover, the majority of the examined plants were liable to be infested with this snail. Generally, the listed hosts can be classified according to the degree of infestation into three categories. These categories were, heavy, moderate and light infestation.The majority of the examined field and vegetables crop at Sharkia governorate were found with moderate infestation by $M$. cartusiana especially Egyptian clover in El-Khatarah (Fakous district), Abou Hamad El-balad and Mashtoul El-Balad. On the other hand, wheat, broad bean, onion, tomato, cucumber, squash, cabbage and eggplant were found with light infestation in different localities.Regarding S. putris it was detected with moderate infestation on Egyptian clover in El-Abbasa and Abou Hammad El-balad (Abou -Hammad district) and ElSahava (Mastoul El-Souk district). It was recorded with light infestation on broad bean, wheat, onion, tomato and strawberry. Regarding the field slug $D$. reticulatum,it was found with light infestation on clover and tomato in El-Sahava (Mashtoul -El Souk) only.Data in Table (3) show that the heavy infestation with M. cartusiana was found in Fayed EL-Balad while it was detectedwith moderate infestation in Om-Azzam (El- Kssasin El-Gadida district) on Egyptian clover, however the rest different examined crops were found with light infestation like broad bean, wheat, maize, watermelon, tomato, strawberry, kidney bean and pepper. Regarding S. putris it was found with light infestation on clover and wheat (El-Dawawis, El-Qoua and ElMahsama villages at El-Ksasin El-Gadida district),( El-Wasfia and Abou-Atwa, Ismailia district) and (Kasfaryt, Fayed village, Fayed district) . 
Table 2. Level infestation with terrestrial molluscs on different crops at certain districts of Sharkhia governorate.

\begin{tabular}{|c|c|c|}
\hline $\begin{array}{c}\text { Location } \\
\text { county/village }\end{array}$ & Land gastropod species & level of infestation on host plants \\
\hline \multicolumn{3}{|l|}{ Abou-Hammad } \\
\hline \multirow[t]{2}{*}{ El-Khaeis } & Succinea putris & Clover $(+)$ \\
\hline & Monacha cartusiana & Clover $(+)$ \\
\hline \multirow[t]{2}{*}{ El-Abasa } & Succinea putris & Clover $(++) \&$ broad bean $(+) \&$ Tomato $(+)$ \\
\hline & Monacha cartusiana & Cucumber $(+) \&$ squash(+) \& Tomato (+) \\
\hline \multirow[t]{2}{*}{ El-Gavaria } & Succinea putris & Clover $(+)$ \\
\hline & Monacha cartusiana & Clover $(+) \&$ wheat $(+)$ \\
\hline Abou-Hammad & Succinea putris & Clover $(++)$ \& wheat $(+)$ \\
\hline El-balad & Monacha cartusiana & Clover $(++)$ \\
\hline \multicolumn{3}{|l|}{ Fakous } \\
\hline El-Khataraha & Monacha cartusiana & $\begin{array}{l}\text { Clover }(++) \text { \& wheat }(++) \& \\
\text { Onion }(+) \& \text { Tomato }(+) \& \\
\text { Kidney bean }(+)\end{array}$ \\
\hline Abou-Shalaby & Monacha cartusiana & $\begin{array}{l}\text { Clover }(+) \text { \& wheat }(+) \& \\
\text { Broad bean }(+) \text { \& onion }(+) \\
\text { Egg plant }(+)\end{array}$ \\
\hline Fakous El-balad & $\begin{array}{l}\text { Monacha cartusiana } \\
\text { Succinea putris }\end{array}$ & $\begin{array}{l}\text { Clover }(+) \text { \& wheat }(+) \text { \& onion }(+) \\
\text { Clover }(+)\end{array}$ \\
\hline El-Fadadna & $\begin{array}{l}\text { Monacha cartusiana } \\
\text { Succinea putris }\end{array}$ & $\begin{array}{l}\text { Clover }(+) \\
\text { Clover }(+) \\
\end{array}$ \\
\hline \multirow{2}{*}{$\begin{array}{l}\text { Mashtooul-El Souk } \\
\text { Moniuer }\end{array}$} & & \\
\hline & $\begin{array}{l}\text { Monacha cartusiana } \\
\text { Succinea putris }\end{array}$ & $\begin{array}{l}\text { clover }(+) \text { \& onion }(+) \\
\text { clover }(+) \& \text { cabbage }(+) \& \text { tomato }(+)\end{array}$ \\
\hline \multirow{3}{*}{$\begin{array}{l}\text { Kafr-Ebrash } \\
\text { Mashtoul-El-balad } \\
\text { El-Sahava }\end{array}$} & Monacha cartusiana & clover $(+)$ \\
\hline & Monacha cartusiana & clover $(++) \&$ onion $(+) \&$ wheat $(+)$ \\
\hline & $\begin{array}{l}\text { Succinea putris } \\
\text { Deroceras reticulatum }\end{array}$ & $\begin{array}{l}\text { clover }(+) \& \text { wheat }(+) \& \\
\text { strawberry }(+) \& \text { tomato }(+) \& \\
\text { taro }(+) \& \text { kidney bean }(+) \\
\text { clover }(++) \& \text { onion }(+) \& \text { wheat }(+) \\
\text { strawberry }(+) \& \text { tomato }(+) \\
\text { clover }(+) \& \text { tomato }(+)\end{array}$ \\
\hline
\end{tabular}

(+) = low infestation, $1-15$ snails $/ 50 \times 50 \mathrm{~cm}$.

$(++)=$ moderate infestation, $16-30$ snails $/ 50 \times 50 \mathrm{~cm}$.

$(+++)=$ heavy infestation, more than 30 snails $/ 50 \times 50 \mathrm{~cm}$. 
Table 3. Level of infestation with terrestrial molluscs on different crops at certain districts of Ismailia governorate.

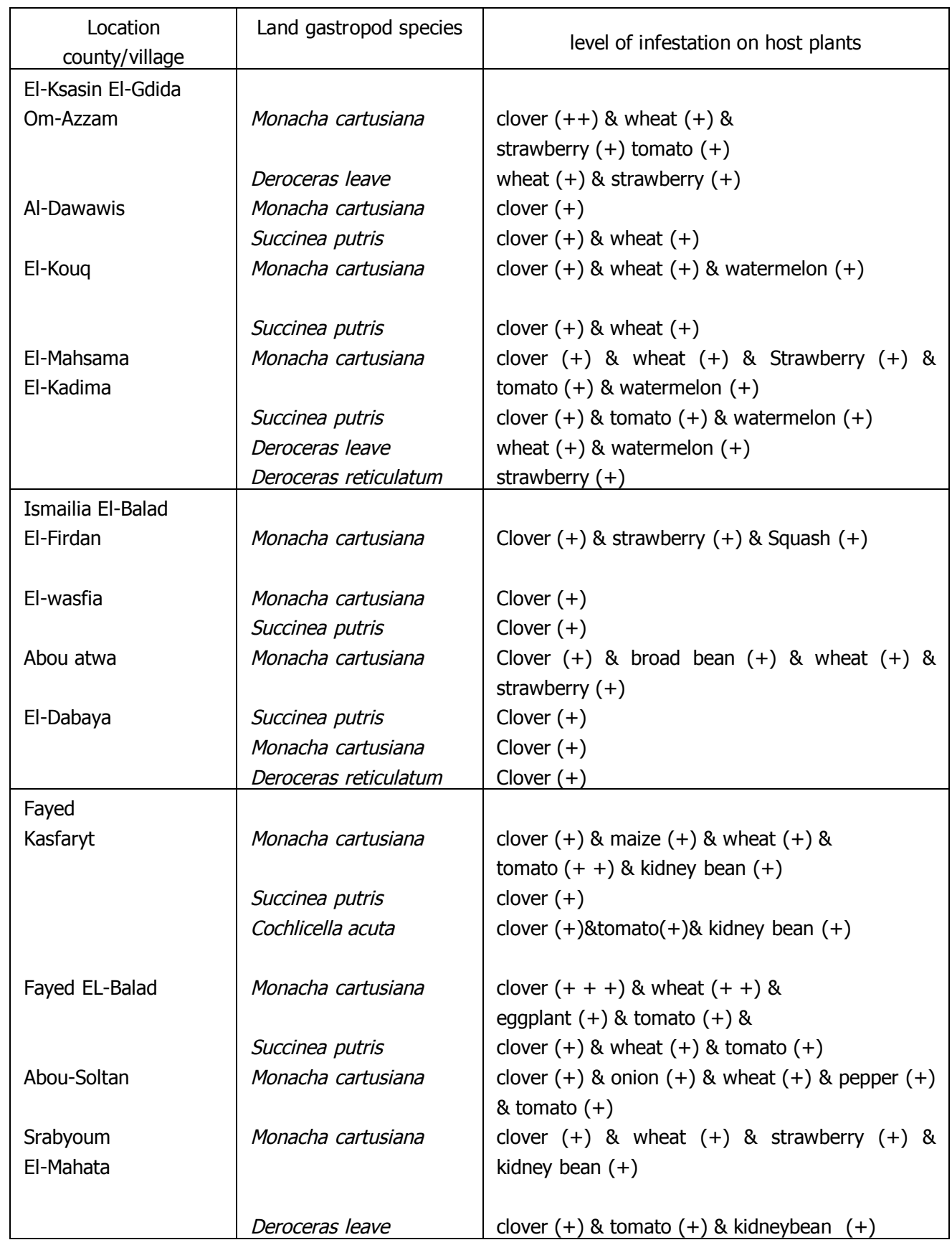

(+) = low infestation, $1-15$ snails $/ 50 \times 50 \mathrm{~cm}$.

$(++)=$ moderate infestation, $16-30$ snails $/ 50 \times 50 \mathrm{~cm}$.

$(+++)=$ heavy infestation, (more than 30 snails $/ 50 \times 50 \mathrm{~cm}$.

Other identified snails showed limited distribution since they were detected in few localities, whereas, $D$. leave abundantly found on strawberry, and wheat and watermelon in (Om Azzam and El-Mahsama El-Kadima village) El-Ksasin El-Gadida 
district respectively, and on Egyptian clover, tomato and kidney bean in Fayed village. However, strawberry was found with light infestation in El-Mahsama El-Kadima village, whereas the slug D.reticulatum was detected for the first time in Ismailia governorate. On the other hand, C. acuta was counted with a relatively low number on Egyptian clover, tomato and kidney bean at Kasfaryt village, Fayed district, Ismailia governorate. Discussing the foregoing results, it is well know that land snails and slugs were recorded as serious pests to agricultural crops in different places in Egypt. The terrestrial snails were found at different governorate attacking many economic crops. For instances, Monacha sp. and Oxychilus sp. were detected in Ismaelia Governorate (El-Okda, 1984), Eobania vermiculata, T. pisana, Hellicella vestalis, M. obstructa, C. acuta, Rumina decollate and Oxychilus sp. were found in Alexandria and Beheira governorate (El-Okda, 1980). Moreover, E. vermiculta, Succinia putris and C. nemoralis were determined at Kafr El-Shiekh, M. cartusiana, C.nemoralis, C. acuta, $O$. alliavus, and Helicella sp. at Damiatta Governorate and M. cartusiana, S. putris, E. vermiculata, C. acuta and C. nemoralis at Dakahlia governorate (El-Deeb et al. 1996). On the other hand, at Sharkia governorate Ghamry et al., 1993, Ismail 1997, Mahrous et al., 2002 and Lokma, 2007 detected certain land snail species on field and vegetable crops.Ismail (1997) reported that Egyptian clover, wheat and broad bean were heavily infested with $M$. cartusiana in six counties while maize and rice were found with light infestation by the same species in Zagazig district. Whereas, Mahrous et al. (2002) reported that $M$. cartusiana was the main pest of field crops in most districts of Sharkia governorate, while $H$. vestalis and $E$. vermiculata were detected on Egyptian clover, broad bean, wheat and maize in Belbies and El-Hussainia districts. However, Succinia sp. was observed on Egyptian clover at Fakous district only. Moreover, Ismail (2004) revealed the snail E. vermiculata were found throughout allover the whole year with low numbers in January and gradually increased to reach to peak in May in orange orchad in Sharkia governorate and the highest numbers were recorded on tree trunks during spring season compared with soil surface. Ismail et al. (2011) reported that $M$. cartusiana and S. putris snails were found at Hehia and Meniet El-kamh while M. cartusiana was found with higher density than S.putris on agricultural crops and weeds at Sharkia governorate. finally Awad (2013) surveyed the existence of four species of land snails M.theba cartusiana,M.cantiana, S.putris and S.elegans in south district of Port Saied region, Port Saied governorate .The population density of all observed land snails was heavier on Egyptian clover followed by wheat and sugar beet,also recorded highest numbers through spring season followed by Autumn and Winter. 


\section{Importance value of some terrestrial molluscs at Sharkia and Ismailia governorate.}

The objective of the present study is to characterize communities of land gastropod species infesting major crops at Sharkia and Ismailia governorate using some ecological parameters i.e. frequency of occurrence, population density and biomass. To accomplish this goal, a total of 360 samples were randomly collected from 3 districts in each of Sharkia and Ismailia governorate. Data in Tables (4\&5) indicated that according to frequency of occurrence $M$. cartusiana was the most frequently species followed by descendingly $S$. putris and $D$. reticulatum. Their absolute frequencies of occurrence were $21.66,12.50$ and $1.11 \%$ respectively at Sharkia governorate. On the other hand, according to frequency of occurrence, $M$. cartusiana was the most frequently species followed descendingly by $S$. putris $>D$. leave $>D$. reticulatum $>C$. acuta, with absolute frequency of occurrence of 28.61 , $5.55,1.11,0.83$ and $0.27 \%$ respectively at Ismailia governorate. According to population density it was found that $M$. cartusiana gained the highest value (10.80) (8.24) followed descendingly by Succina putris (8.82) (5.40) and D. reticulatum (2.25) (4) snails per sample) at Sharkia and Ismailia governorate respectively. While $D$. leave and $C$. acuta were detected with values (1.25) and (1) at Ismailia governorate. The relative population density for the identified species at Sharkia and Ismailia Governorate were M. cartusiana $(49.38 \%)$ \& (41.42\%), Succina putris $(40.32 \%)$ \& (27.14\%) and Slug, D.reticulatum (10.28\%) \& (20.11\%) respectively. However, according to biomass criterion $D$. reticulatum weighed $0.500 \mathrm{gm} / \mathrm{slug}$ followed by $M$. cartusiana $(0.475)>C$. acuta $(0.220)>D$. leave $(0.200)>$ Succinea putris 0.191 (gm / snail). Consequently relative biomass showed the same arrangement. Descending orders of land snail species as evaluated by frequency of occurrence, population density, biomass and importance value at Sharkia and Ismailia governorate. It is clear that they showed different arrangement. For example, $M$. cartusiana was the first one according to frequency of occurrence and apopulation density and biomass at Ismailia governorate. While according to biomass it was the second. Moreover, S.putris changed its position from second according to frequency of occurrence or population density to light based on biomass.Since frequency of occurrence, population density and biomass gave different results. 
Table 4. Importance value of some terrestrial molluscs species at Sharkia governorate.

\begin{tabular}{|c|c|c|c|c|c|c|c|}
\hline \multirow{2}{*}{ Snail species } & \multicolumn{2}{|c|}{$\begin{array}{c}\text { Frequency occurrence } \\
\text { \% }\end{array}$} & \multicolumn{2}{c|}{$\begin{array}{c}\text { Population } \\
\text { Density }\end{array}$} & \multicolumn{2}{c|}{$\begin{array}{c}\text { Biomass } \\
\text { (gm) }\end{array}$} & Importance \\
\cline { 2 - 7 } & Absolute & Relative & Absolute & $\begin{array}{c}\text { Relative } \\
(\%)\end{array}$ & Absolute & $\begin{array}{c}\text { Relative } \\
(\%)\end{array}$ & \\
\hline M. cartusiana & 21.66 & 61.41 & 10.80 & 49.38 & 0.475 & 40.70 & 151.49 \\
\hline S. putris & 12.50 & 35.44 & 8.82 & 40.32 & 0.192 & 16.45 & 92.21 \\
\hline D. reticulatum & 1.11 & 3.14 & 2.25 & 10.28 & 0.500 & 42.84 & 56.26 \\
\hline
\end{tabular}

Table 5. Importance values some terrestrial molluscs species at Ismailia governorate.

\begin{tabular}{|c|c|c|c|c|c|c|c|}
\hline \multirow{2}{*}{ Snail species } & \multicolumn{2}{|c|}{$\begin{array}{c}\text { Frequency } \\
\text { occurrence } \\
\%\end{array}$} & \multicolumn{2}{c|}{$\begin{array}{c}\text { Population } \\
\text { Density }\end{array}$} & \multicolumn{2}{c|}{$\begin{array}{c}\text { Biomass } \\
(\mathrm{gm})\end{array}$} & $\begin{array}{c}\text { Importanc } \\
\text { e value }\end{array}$ \\
\cline { 2 - 7 } & Absolute & Relative & Absolute & $\begin{array}{c}\text { Relative } \\
(\%)\end{array}$ & Absolute & $\begin{array}{c}\text { Relative } \\
(\%)\end{array}$ & \\
\hline M. cartusiana & 28.61 & 78.66 & 8.24 & 41.42 & 0.475 & 029.93 & 150.01 \\
\hline S. putris & 5.55 & 15.25 & 5.40 & 27.14 & 0.192 & 12.09 & 54.48 \\
\hline D. reticulatum & 0.83 & 2.28 & 4 & 20.11 & 0.500 & 31.50 & 53.89 \\
\hline D. leave & 1.11 & 3.05 & 1.25 & 6.28 & 0.200 & 12.60 & 21.93 \\
\hline C. acuta & 0.27 & 0.74 & 1 & 5.02 & 0.220 & 13.86 & 19.62 \\
\hline
\end{tabular}

$*$ Importance value $=$ Relative frequency + relative density + relative biomass.

They can be combined together in hope of having a figure that would relate aspects of the three parameters.Therefore, the relationship of three parameters was calculated as importance value according to Norton (1978). Generally, terrestrial gastropods can be arranged descendingly according to their importance value of Sharkia Governorate as follows: M. cartusiana $>$ Succinia putris $>D$.reticulatum, while the repection values it Ismailia Governorate were: M. cartusiana > Succinia putris $>D$. reticulatum $>D$. leave $>C$. acuta. Regarding frequency of occurrence and population density of terrestrial snails infesting field crops in five districts of Sharkia Governorate Lokma (2007) showed that based on frequency occurrence, for instances, on clover. M. cartusiana occurred more frequently in Meniet El-Kamh, Fakous and Zagazig compared to Belbies and Kafr -Sakr. On the other hand, the highest values of population density for such snail were found in Fakous and Meniet El-Kamh followed by Belbies, Kafr-Sakr and Zagazig. However, Shoieb Maha (2008) showed that the white snail Theba pisana the common terrestrial snails at Suez Canal area, while Monacha obstructa was recorded highly abundance in Ismaelia governorate and caused economic damage on Egyptian clover and several vegetable crops.She reported that the garden snail Eobania vermiculata recorded only on ornamental plants in public gardens. The conical snail $C$. acuta was recorded with heavy infestation on mango trees in Ismaelia Governorate, Xeroptica vestalis recorded at North Sinai Governorate in Raffah area, the snail Succinea campestris was noticed as the first time in Ismaelia Governorate. 
Consequently, determination of the infested localities and dispersal to neighboring edge of Govenorates can be very useful in suggestion to make local quarantine to prevent dispersal of land snail all over plantations of Sharkia and Ismailia governorate. Moreover, during the last few years, land snails were dispersed quickly at Sharkia governorate.For example, Ismail (1997) showed that 17 localities representing 7 districts were infested with land snail species. However, AbdEL-Aal (2001) indicated that 44 localites representing 12 districts were infested with land snails at Sharkia governorate. Furthermore, Lokma (2007) showed that the infestation with land snails was obviously increased in the last few years at Sharkia governorate. Number of infested localities was 84 villages with percent infestation of $18.14 \%$ during 2003. These figures were increased to 111 villages with percent infestation of 23.97\% during 2004.Finally, Shetaia et al. (2009) reported that the glassy clover snail Monacha cartusiana and the amber snail, Succinea putris were found at Awlad-Sakr and Abo-Kapeer counties, Sharkia governorate. M. cartusiana sanil was found with higher density than $S$. putris. The majority of examined crops were found with heavy infestation with $M$. cartusiana snail while $S$. putris were recorded with moderate or light infestation in the examined localities.The land snail species can be arranged descedingly, according to its importance values as follow: E.vermiculata>, $M$. cartusiana $>$, C.acuta $>$, H. vestalis.

\section{REFERENCES}

1. Abd El-Aal, S. M. 2001. Studies on certain land snails at Sharkia Governorate. M.Sc. Thesis, Fac. Agric., Zagazig Univ. 160 pp.

2. Arafa A. A. I. 2006. Studies on terrestrial molluscs in some Delta Governorate. Ph.D. Thesis, Fac. Agric., AL-Azhar Univ., 167 pp.

3. Awad ,M. H. M. 2013. Logical control and population density studies on land snails in South district of port Said, portsaied Governorate, Egypt. Acad. J. Biolog.Sci, 5 (2):47:63.

4. Baker, G.H. 1989. Damage, population dynamics, movement and control of pest helicid snails in Southern Austria. In British crop protection (BCPC) Monograph. No. 41.Slug and Snail pests in Agriculture. ED. Henderson,I.F.,175-185.

5. El-Deeb, H. I., Shereef, G. H., Essa, N. H. and Fouad, Maha. M. 1996. Survey and distribution of land mollusca of some nurseries at Greater Cairo (Egypt). J. Agric. Sci. Mansoura Univ., 21 (12): 4525 - 4535.

6. El-Okda, M. M. K. 1980. Land snails of economic importance on vegetable crops at Alexandria and neighbouring regions. Agric. Res. Rev., 58 (1): $79-85$.

7. El-Okda, M. M. K. 1984. Land mollusca infestation and chemical control in ElIsmaelia Governorate. Agric. Res. Rev., 62 (1): 87 - 92. 
8. Ghamry, E. M., El-Deeb, H. I. and Kokab, Y. A. 1993. Ecological and morphological studies on certain land snails at Sharkia Governorate. Egypt. J. Appl. Sci., 8 (11): 213: 225.

9. Godan, D. 1983. Pest slugs and snails, biology and control. Springer-Verlag Berlin, Heidelberg. 445 pp.

10. Ismail, Sh. A. A. 1997. Ecology, biology and control of certain terrestrial snails infesting some vegetable and field crops in Sharkia Governorate. Ph.D. Thesis, Fac. Agric., Zagazig Univ., 130 pp.

11. Ismail, Sh. A. A. 2004. Ecobiological studies on the brown garden snail Eobania vermiculata Muller under laboratory and field conditions in Sharkia Governorate.Zagazig J.Agric.Res.,31(1):293-305

12. Ismail, Sh. A. A., Shetia,S.Z.S.,Arafa,A.I and Abd-El Atty,S.F. 2011. Incidance and seasonal fluctuation of certain land gastropod species associated with some crops and weeds at Sharkia Governorate. J. Plant Protec \& Pathol., Mansoura Univ., 2(12):1103-1110.

13. Kassab, A. and Daoud, H. 1964. Notes on the biology and control of land snails of economic importance in the U.A.R. Agric. Res. Rev., 42: 77-98.

14. Lokma, M.H.E. 2007. Studies on some terrestrial gastropods injurious to field crops at Sharkia Governorate M.Sc. Thesis, Fac. Agric., Zagazig Univ., 147 pp.

15. Mahrous, M. E., Ibrahim Mervat, H. and Abd El- Aal, E. M. 2002. Occurance, population density and importance value of land snails infesting different crops in Sharkia Governarte, Egypt. Zagazig J. Agric. Res., 29 (2): 613 - 629.

16. Norton, D. C. 1978. Ecology of plant parasitic nematodes. Wiley, New York, 268 pp.

17. Shetia,S.Z.S.,Ismail,SH.A,A and Abdel Kader Samah M. 2009. Survey, population dynamics and importance value of certain land snail species infesting differed crops in Sharkia Governorate, Egypt. Acad. J. Biolog.Sci.,1 (1) :37-43.

18. Shoieb Maha, A. 2008 . Occurnce distribution of terresitrial molluscs in User Canal governorate and Noth of Sinai. Egypt. J. Agric. Res., 86 (3): 989-994.

19. Staikou, A. and Lazaridou- Dimitriadou, M. 1990. Aspects of the life cycle, population dynamics, growth and secondary production of the snail Monacha cartusiana (Muller, 1884) (Gastropoda: Pulmonata) in Greece. Malacologia, 31 (2): $353-362$. 


\section{دراسات بيئية على بعض الرخويات الأرضية

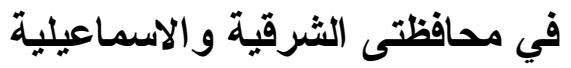

$$
\begin{aligned}
& \text { جاد حمادة حسن راضى'، أحمد عبد الوهاب عبد الجواد'، }
\end{aligned}
$$

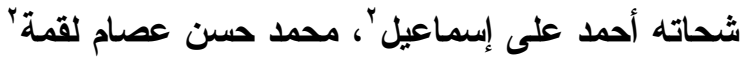

$$
\begin{aligned}
& 1 \text { - قسم وقاية النبات - كلية الزراعة بمشتهر - جامعة بنها. } \\
& \text { r - معه بحوث وقاية النباتات - مركز البحوث الزراعية - الدقى - جيزه. }
\end{aligned}
$$

أجريت التجارب الحقلية لحصر وكثافة التعداد وقيمة الأهمية للرخويـات الارضــبة التـي تصيب بعض محاصيل الخضر و الحقل بمحافظتى الثرقية والاسماعيلية ـ نم تحديد خمس انو اع مــن

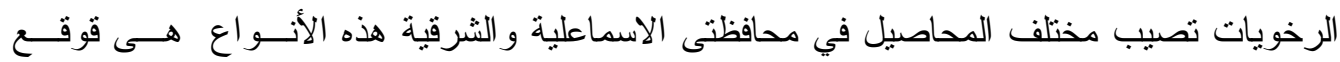

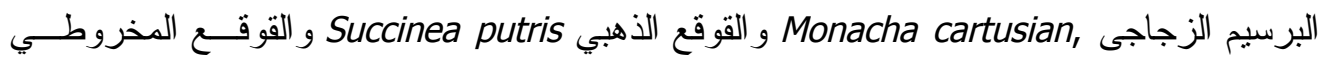
Deroceras و و البز اقة الملساء Dechlicella acuta reticulatum

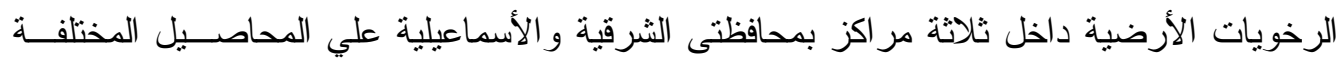

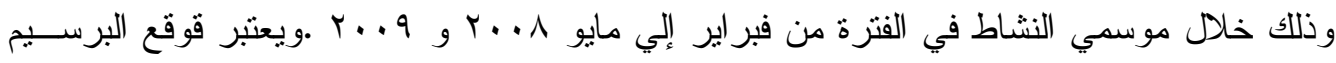
الزجاجي هو الأكثر شيوعا علي محاصيل الحقل و الخضر • وعموما إختلفت الكثافة العددية من عائل

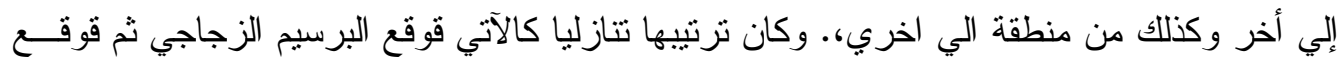

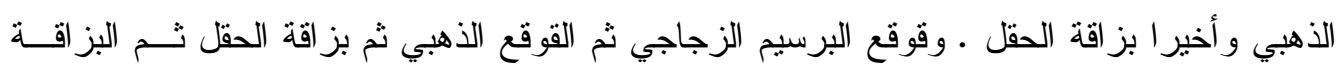
الملساء و أخير ا القوقع المخروطي في محافظتى الثرقية و الإسماعيلية علي الترتيب. 